\title{
First record of Pelagia noctiluca (Forssk ål, 1775) on the coast of Syria
}

\author{
Hani Durgham*, Samar Ikhtiyar and Reem Ibraheem
}

\begin{abstract}
Background: Alien jellyfish species are increasing in the Mediterranean coast of Syria. The Lattakia port area has been monitored since 2010, and three gelatinous species (Phyllorhiza punctata, Cassiopea andromeda and Salpa maxima) were recorded for the first time in Syrian coastal waters (Durgham, J Oceans Oceanogr 5:153-155, 2011; Siokou et al, Mediterr Mar Sci 14:238-249, 2013; Bilecenoglu et al, Mediterr Mar Sci 14:463-480, 2013).

Methods: Two specimens of Pelagia noctiluca were caught in the coastal waters about $3 \mathrm{~km}$ North West of Lattakia port, after Several hundred dives have been made at more than 20 sites down to $40 \mathrm{~m}$ depth.

Results and conclusion: This research led to the identification of the first record of the mauve stinger Pelagia noctiluca (Forsskål, 1775) on the Mediterranean coast of Syria.

This jelly fish has been observed on 14 June 2014 near Lattakia Port, and Several observations indicate that these individuals may have been transported via ballast water.
\end{abstract}

Keywords: Cnidaria, Mauve stinger, Syria, Alien species

\section{Introduction}

The mauve stinger Pelagia noctiluca is a holoplanktonic Scyphozoan (i.e. lacking a benthic polyp stage) (Purcell, 2005). This jellyfish has a wide distribution in all warm and temperate waters and is found in Bermuda (Sterrer, 1986), the Mediterranean Sea (Goy et al., 1989; Ferraris et al., 2012), off the coast of California (Fox \& Millott 1954), and in the Atlantic Ocean (Larson et al. 1991), and is frequently by far the most common jellyfish species throughout the year.

In the Mediterranean Sea Pelagia noctiluca has occurred in both the western basin (Daly Yahia et al. 2003; Hamza, 1990; Ranson, 1925) and the eastern basin (Goy et al., 1990; Lakkis et al., 1990; Lakkis, 2013; Piccinetti Manfrin \& Piccinetti 1983; Bingel, 1991; Bingel et al. 1991; Axiak et al. 1991; Benovic 1984, Malej, 1989), Pelagia noctiluca shows periotic population peaks with occasional devastating impact in certain parts of the Mediterranean; these peaks occur on average at twelve year intervals, and have been related to climatic factors (Goy et al., 1989). The species has been recorded in other Mediterranean areas (Tunisian coast, Maltese waters, the Aegean and

\footnotetext{
* Correspondence: hmdurgham@gmail.com

Department of Marine Biology, High Institute of Marine Research, Tishreen University, Lattakia, Syria
}

(C) 2016 Durgham et al. Open Access This article is distributed under the terms of the Creative Commons Attribution 4.0 International License (http://creativecommons.org/licenses/by/4.0/), which permits unrestricted use, distribution, and reproduction in any medium, provided you give appropriate credit to the original author(s) and the source, provide a link to the Creative Commons license, and indicate if changes were made. The Creative Commons Public Domain Dedication waiver (http://creativecommons.org/publicdomain/zero/1.0/) applies to the data made available in this article, unless otherwise stated.

\section{Results and discussion}

Two specimens of Pelagia noctiluca (Figs. 1 and 2) were caught in the coastal waters of Lattakia, about $3 \mathrm{~km}$ North West of Lattakia port $\left(35^{\circ} 32^{\prime} 9.44^{\prime \prime} \mathrm{N}, 35^{\circ} 43^{\prime} 17.13^{\prime \prime} \mathrm{E}\right)$, on 14 June 2014.

The specimens had a hemispherical and transparent umbrella, the exumbrella surface covered with small colorless warts. Freshly collected live animals showed a mauve coloration in the gonads, tentacles and oral arms (Fig. 1); and from the umbrella margin eight thick tentacles arose between successive lappets; the tentacles were 


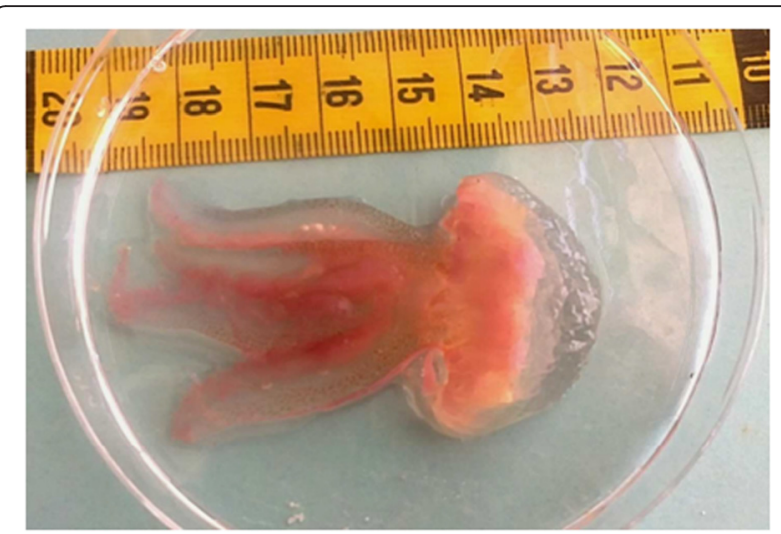

Fig. 1 Freshly collected live specimen of Pelagia noctiluca (Forsskål, 1775) Bell diameter $32 \mathrm{~mm}$ (Image by R. Ibraheem)

rounded, somewhat shorter or equal in length to the oral arms (5 and $6 \mathrm{~cm}$ respectively). Bell diameter and wet weight for the $2 P$. noctiluca specimens were 25 and 32 $\mathrm{mm} ; 10.41$ and $28 \mathrm{~g}$ respectively.

The temperature and salinity at the sampling time were $24^{\circ} \mathrm{C}$ and $39.3 \%$, respectively. The two specimens were collected at depths of $28-30 \mathrm{~m}$, and it was observed that these specimens were swimming with a strong current that was coming up from the south. The Lattakia port area has been monitored since 2010, and three gelatinous species (Phyllorhiza punctata, Cassiopea andromeda and Salpa maxima) were recorded for the first time in Syrian coastal waters (Durgham, 2011; Siokou et al., 2013; Bilecenoglu et al. 2013). The presence of these gelatinous species alongside Pelagia noctiluca in the Lattakia port area may be due to transportation via ballast water of oil tankers and other ships. Pelagia noctiluca has been assigned to five size classes using measurements of bell diameter: $<1.0 \mathrm{~cm} ; 1.0<3.5 \mathrm{~cm}$ (Immature medusa); $3.5<6.0 \mathrm{~cm}$ (Conditionally mature); $6.0<8.5 \mathrm{~cm}$ (Mature);

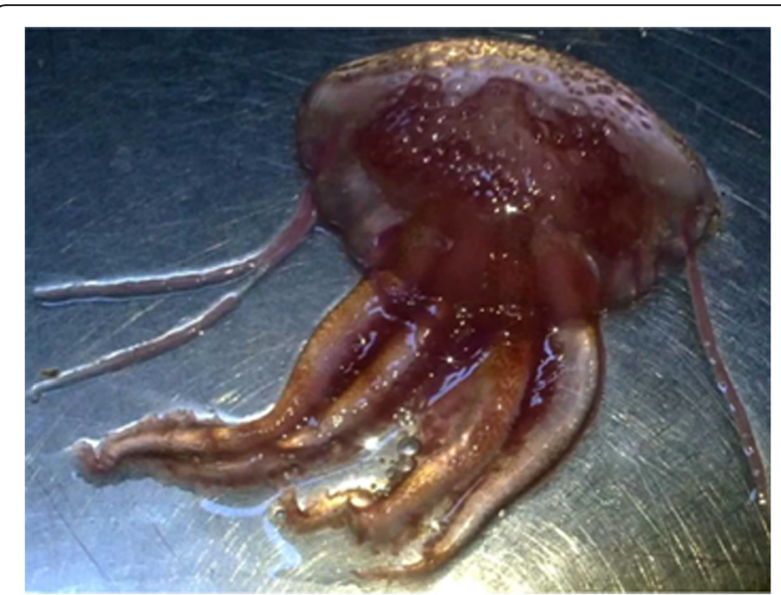

Fig. 2 Preserved specimen of Pelagia noctiluca (Forsskål, 1775 Bell diameter $25 \mathrm{~mm}$ (Image by H. Durgham)
$>8.5 \mathrm{~cm}$ (Malej \& Malej, 2004). According to this classification our individuals are immature medusae. This classification, with the presence of these individuals close to an important commercial port in Syria, along with the fact that larvae of Pelagia noctiluca have not been recorded in any plankton samples on the Syrian coast, all support the hypothesis that these individuals may have been transported via ballast water.

\section{Acknowledgement}

The authors would like to thank Prof. Abdul karim Mohammad (Dean of The High Institute of Marine Research) for his cooperation and sponsorship.

\section{Authors' contributions}

$\mathrm{HD}$ and SI has contributed to all aspects of the research work presented here including caught and identification of jellyfish, write and finalizing the manuscript. RI contributed to taking a photograph of one of the two jellyfish specimens at the zooplankton laboratory of the High Institute of Marine Research. All authors read and approved the final manuscript.

\section{Competing interests}

The authors declare that they have no competing interests.

Received: 6 June 2016 Accepted: 6 June 2016

Published online: 25 July 2016

\section{References}

Axiak V, Galea C, Schembri PJ. Coastal aggregations of the jellyfish Pelagia noctiluca (Scyphozoa) in the Maltese coastal waters during 1980-1986. In Jellyfish blooms in the Mediterranean, Proceedings of the II Workshop on Jellyfish in the Mediterranean Sea, MAP Technical Reports Series, No.47. Athens: UNEP; 1991. p. 32-40.

Benovic A. Appearance of the jellyfish Pelagia noctiluca in the Adriatic Sea during the summer season of 1983, In Workshop on Jellyfish Blooms in the Mediterranean, Athens, Greece, 31 October - 4 November 1983. Athens: UNEP; 1984. p. 3-8.

Bilecenoglu M, Alfaya JEF, Azzurro E, Baldacconi R, Boyaci YQ, Circosta V, et al. New Mediterranean Marine biodiversity records (December, 2013). Mediterr Mar Sci. 2013;14(2):463-80.

Bingel F. Occurrence of jellyfish at the Black Sea- Marmara junctions of the Bosphorus. In Jellyfish blooms in the Mediterranean, Proceedings of the II Workshop on Jellyfish in the Mediterranean Sea. MAP Technical Reports Series, No.47. Athens: UNEP; 1991. p. 58-64.

Bingel F, Avsar D, Gucu AC. Occurrence Of jellyfish in Mersin Bay. In Jellyfish blooms in the Mediterranean, Proceedings of the II Workshop on Jellyfish in the Mediterranean Sea. MAP Technical Reports Series, No. 47. Athens: UNEP; 1991. p. 65-71.

Daly Yahia MN, Goy J, Daly Y-KO. Distribution and ecology of medusa and Scyphomedusae (Cnidaria) in Tunis Gulf (SW Mediterranean). Oceanol Acta. 2003:26:645-55.

Durgham H. First records of Phyllorhiza punctata von Lendenfeld, 1884 (Cnidaria: Rhizostomeae) from the Mediterranean Coast of Syria. Int J Oceans Oceanogr. 2011;5(2):153-5.

Ferraris M, Berline L, Lombard F, Guidi L, Elineau A, Mendoza-Vera JM, et al. Distribution of Pelagia noctiluca (Cnidaria, Scyphozoa) in the Ligurian Sea (NW Mediterranean Sea). J Plankton Res. 2012:34(10):874-85.

Fox DL, Millott N. The pigmentation of the jellyfish Pelagia noctiluca (Forskal) var. panopyra Peron \& Lesueur. Proc R Soc Lond Ser B. 1954;142:392-408.

Goy J, Morand P, Etienne M. Long-term fluctuations of Pelagia noctiluca (Cnidaria, Scyphomedusa) in the Western Mediterranean Sea. Prediction by climatic variables. Deep-Sea Res. 1989;36(2A):269-79.

Goy J, Lakkis S, Zeidane R. Medusae of the Eastern Mediterranean. Bull Inst Océanogr. 1990;7:79-88. Monaco, No Special.

Hamza A. Sur la prolifération des méduses sur certaines côtes Tunisiennes. Rapp Doc Inst Nat Sc Tech Océanogr Pêche Salambô. 1990;3:1-9.

Lakkis S. Le Zooplancton Marin du Liban (Méditerranée Orientale). Biologie, Biodiversité, Biogéographie. Aracne Editrice, ISBN 978-88- 548 6334-7, Rome, Italie; 2013. p. 562 
Lakkis S, Avian M, Del Negro P, Rottini-Sandrini L. Les Scyphoméduses du Bassin Levantin (Beyrouth) et de l'Adriatique du nord (golf de Trieste): Comparaison faunistique et écologique. Rapp Comm int Mer Médit. 1990;32(1):220.

Larson RJ, Mills CE, Harbison GR. Western Atlantic midwater hydrozoan and scyphozoan medusae: in situ studies using manned submersibles. Hydrobiologia. 1991;216:311-7.

Malej A. Behaviour and trophic ecology of the jellyfish Pelagia noctiluca (Forsskal, 1775). J Exp Mar Biol Ecol. 1989;126:259-70.

Malej A, Malej AJR. Invasion of the jellyfish Pelagia noctiluca in the Northern Adriatic: a non-success story. In: Dumont $H$, editor. Aquatic Invasion in the Black, Caspian, and Mediterranean Seas. Dordrecht: Kluwer Academic Publishers; 2004. p. 273-85.

Piccinetti Manfrin G, Piccinetti C. Distribution de Pelagia noctiluca(Forsk I) en Méditerranée dans l'été 1983, In Workshop on Jellyfish Blooms in the Mediterranean, Athens, Greece, 31 October - 4 November, 1983. Athens: UNEP; 1983. p. 25-32.

Purcell J. Climate effects on formation of jellyfish and ctenophore blooms: a review. J Mar Biol Assoc U K. 2005:85:461-76. doi:10.1017/ s0025315405011409.

Ranson G. Quelques observations sur le plankton et liste des méduses recueillies par «la tanche» pendant la croisière de 1924. Bull Mus Natl Hist Nat. 1925;31:379-82.

Siokou A, Ates S, Ayas D, Ben SJ, Chatterjee T, Dimiza M, et al. New Mediterranean Marine biodiversity records (June 2013). Mediterr Mar Sci. 2013;14(1):238-49.

Sterrer W. Marine fauna and flora of Bermuda: A systematic guide to the identification of marine organisms. New York: John Wiley \& Sons, Inc; 1986. p. 742.

\section{Submit your next manuscript to BioMed Central and we will help you at every step:}

- We accept pre-submission inquiries

- Our selector tool helps you to find the most relevant journal

- We provide round the clock customer support

- Convenient online submission

- Thorough peer review

- Inclusion in PubMed and all major indexing services

- Maximum visibility for your research

Submit your manuscript at www.biomedcentral.com/submit

C Biomed Central 